\title{
Maternal attitudes and their influence on the creativity level of preschool children
}

\author{
Kimberly Ann Hellen \\ West Virginia University
}

Follow this and additional works at: https://researchrepository.wvu.edu/etd

\section{Recommended Citation}

Hellen, Kimberly Ann, "Maternal attitudes and their influence on the creativity level of preschool children" (1999). Graduate Theses, Dissertations, and Problem Reports. 1018.

https://researchrepository.wvu.edu/etd/1018

This Thesis is protected by copyright and/or related rights. It has been brought to you by the The Research Repository @ WVU with permission from the rights-holder(s). You are free to use this Thesis in any way that is permitted by the copyright and related rights legislation that applies to your use. For other uses you must obtain permission from the rights-holder(s) directly, unless additional rights are indicated by a Creative Commons license in the record and/ or on the work itself. This Thesis has been accepted for inclusion in WVU Graduate Theses, Dissertations, and Problem Reports collection by an authorized administrator of The Research Repository @ WVU. For more information, please contact researchrepository@mail.wvu.edu. 


\title{
Maternal Attitudes and their Influence on the Creativity Level of Preschool Children
}

\author{
Kimberly Ann Hellen \\ Thesis submitted to the \\ College of Agriculture and Forestry \\ at West Virginia University \\ in partial fulfillment of the requirements \\ for the degree of \\ Master of Science \\ in \\ Family and Consumer Sciences \\ Wanda Franz, Ph.D., Chair \\ Carol Markstrom, Ph.D. \\ Barbara Warash, Ed.D.
}

Department of Family and Consumer Sciences

Morgantown, West Virginia

1999

Keywords: Creativity, Parental Influence, Preschool Children

Copyright 1999 Kimberly Ann Hellen 


\title{
ABSTRACT \\ MATERNAL ATTITUDES AND THEIR INFLUENCE ON THE CREATIVITY LEVEL OF PRESCHOOL CHILDREN
}

\author{
Kimberly Ann Hellen
}

The purpose of the study was to determine if maternal attitudes influenced the creativity of preschool children. The Torrance Test of Thinking Creatively in Action and Movement (TCAM) was used to measure the creativity level of the children. The Parent As A Teacher (PAAT) was used to assess maternal attitudes. The subjects in this project were 52 preschool children. Maternal attitudes were not significantly related to the creativity level of preschool children. Socioeconomic status had significant effects on the PAAT overall, creativity and control subscales. Socioeconomic status was a poor predictor of child TCAM scores and the additional PAAT subscales. ANOVAs were run separately for each of the subscales of the TCAM and PAAT, as well as total TCAM and PAAT scores, with socioeconomic being the independent variable in each. The PAAT overall, creativity and control subscales were significant. The limitations and implications for future research in the area of preschool children's creativity and maternal influence are discussed. 
This thesis is dedicated in memory of:

Paul E. Dunham, Sr.

Charles H. Franks, Jr.

Pauline Kiger

Robert Weller

and

David Bryan (WVU Alumnus) 


\section{ACKNOWLEDGMENTS}

First I would like to Dr. Wanda Franz, my committee chair person, for all of her time, advice and assistance. My other two committee members, Dr. Carol Markstrom and Dr. Bobbie Warash, were also a valuable asset to have on "my side". Their comments and suggestions were also very helpful. Michael Foley, who assisted in the collection of data, was a joy to work with. I am grateful for his time and assistance. A thank you is also extended to my friend and assistant, Sherry Burchett, who was helpful and supportive in all aspects of this project!

An extra special thank you is extended for Kathy Fletcher for her much appreciated "statistical" and computer assistance.

I would like to thank Mon County Head Start, Pleasant Day Schools, METC Kids, Inc., and Scott's Run Settlement House for their assistance in the completion of the research.

I would like to thank my husband, Damon, for his support and all the late nights he shared with me at the library while I gathered literature and for trying to help me with the statistics. It's the thought that counts!

A special thank you is extended to my family. They have supported me throughout my life in all my endeavors. Their constant love and support have helped me achieve many goals. Thanks Mom and Dad! I would like to add a "special" thanks to my Dad for the extended use of his computer and economic resources. Also thank you to Howie for going to the library with me and trying to help me with EXCEL. 
Finally, I would like to thank my supervisor, Richard Beto, for making it possible to attend classes and take time off from work in order to conduct the necessary research, while maintaining a full-time position. 


\title{
TABLE OF CONTENTS
}

\begin{abstract}
Dedications

Acknowledgments

Table of Contents vi
\end{abstract}

\section{CHAPTERS}

$\begin{array}{lll}\text { ONE INTRODUCTION } & 1\end{array}$

TWO LITERATURE REVIEW 4

Creativity and Intelligence in Young Children 4

$\begin{array}{ll}\text { The Effect of School of Creativity } & 7\end{array}$

$\begin{array}{ll}\text { Creativity and Play } & 9\end{array}$

Creativity and Parental Influence 11

Socioeconomic Status (SES) Implications 13

$\begin{array}{ll}\text { Summary } & 16\end{array}$

$\begin{array}{ll}\text { Purpose of this Study } & 17\end{array}$ 
$\begin{array}{lll}\text { THREE METHODS } & 20\end{array}$

$\begin{array}{ll}\text { Subjects } & 20\end{array}$

$\begin{array}{ll}\text { Measures } & 21\end{array}$

$\begin{array}{ll}\text { TCAM } & 21\end{array}$

$\begin{array}{ll}\text { PAAT } & 25\end{array}$

Hollingshead Four Factor Index of Social Status 26

$\begin{array}{ll}\text { Procedure } & 26\end{array}$

$\begin{array}{llr}\text { FOUR } & \text { RESULTS } & 28\end{array}$

Inter-Rater Reliability 28

$\begin{array}{ll}\text { Table } 1 & 28\end{array}$

Means and Standards Deviations 28

$\begin{array}{ll}\text { Table } 2 & 29\end{array}$

Main Hypothesis $\quad 30$

Correlations between the TCAM and the PAAT Subscales 30

$\begin{array}{ll}\text { Table } 3 & 31\end{array}$

Socioeconomic Status $\quad 32$

Table $4 \quad 33$

Table 5 
Socioeconomic Status Effects 38

Parental Influence $\quad 40$

Limitations of the Study $\quad 41$

Study Contributions $\quad 42$

Future Research $\quad 44$

$\begin{array}{ll}\text { Bibliography } & 46\end{array}$

$\begin{array}{ll}\text { Appendices } & 53\end{array}$

A. Parental/Guardian Consent Form 54

B. Information Letter $\quad 56$

C. Maternal Questionnaire 58

D. Parent As A Teacher Inventory (PAAT) 60

E. Thinking Creatively in Action and Movement (TCAM) 67 


\section{CHAPTER ONE}

\section{Introduction}

Children are born with certain traits, however, it is up to the environment to nurture and enhance these traits. Creativity is believed to be one of these traits. Some researchers disagree on what creativity is and how to assess it (Lowenfield \& Brittain, 1975). As with many other behaviors, the nature versus nurture debate exists. Even though there is controversy on the definition of creativeness, most scholars agree that creativity is one of the highest forms of cognitive functioning and is positively correlated with high achievement (Torrance, 1970).

Lowenfield and Brittain (1975) claim that every child is born creative. Moran, Sawyers, Fu, and Milgram (1985) agree that creativity is "natural" in young children. Torrance (1970) believes that creativity needs to be nurtured. Since all children are born with the capability of being creative, each child should be given a chance to learn to use the gift of creativity. Meador (1992) claims that many abilities, creativity included, emerge

during the preschool years. By providing stimulating materials, activities and social interactions, creativity needs no direction because it will blossom all by itself.

Every child has the potential to be creative in one way or another (Shimm \& Ballen, 1996). Therefore it is essential that 
parents should nurture the creativity that nature has given a child. Parents can easily ignite a child's imagination, unfortunately they can also extinguish a child's imagination without realizing it. By introducing stimulating materials, participating in pretend play and welcoming "messy" play, parents are fostering creativity in youngsters. However, by criticizing "messy" play and not providing adequate stimulation parents can also close the doors that lead to creative beginnings.

Imaginative play is an important factor in the development of children's creativity. Singer (1985) proposed that imaginative play leads to a happier childhood, as well as enhancing creativity. Play with peers and adults is equally relevant for the healthy creative development of preschoolers. Dansky (1980) believes that make-believe play enhances creativity. An environment full of play opportunities, whether it be at home or at preschool, promotes creative development in young children.

Initially, nursery schools were designed to provide custodial services for disadvantaged families and assist in the teaching of the children of these families (Beatty, 1995). However, over the years, nursery schools have been transformed into institutions that offer an organized educational experience for all young children. Non-working parents are often motivated to enter their children in a preschool in search of additional environmental stimulation. According to Zimiles (1986) 
preschool programs were designed to provide an environment for creative play, social play interactions and intellectual stimulation while paving the way for a smooth transition into kindergarten. Parents often have a child's creative development in mind whenever entering them into a preschool setting.

There is an abundance of research on creativity and children. Research performed includes: (a) the influence of cognitive processing on creative ability (Daugherty, White, \& Manning,1995), (b) the relationship of creativity and intelligence (Fuchs-Beauchamp, Karnes, \& Johnson, 1993), (c) the role of schooling in the development of creative thinking in young children (Thomas \& Berk, 1981), (d) imaginative play (Moran, Sawyers, Fu \& Milgram, 1984), (e) original thinking (Moran, Milgram, Sawyers \& Fu, 1983), and (f) pretend play in childhood (Fein, 1981).

Unfortunately, not much research has been conducted concerning the influence that parents have on a child's creativity level. Clay (1996) examined parental influence on the creativity of preschoolers and was unable to report any significant findings concerning parental influence. The present study is an extension of the Clay study, however this study also examined the effects of socioeconomic status on maternal attitudes and the creativity levels of children. 


\section{CHAPTER TWO}

\section{Literature Review}

\section{Creativity and Intelligence in Young Children}

The preschool years are like the beginning of a rainbow (Meador, 1992). These years are filled with excitement, and numerous experiences provide the groundwork for the growth and development of children. Between the ages of three and five there is an awakening of individual creative style in children that is thought to continue to adulthood (Rosenthal, 1983). The continuance of creative thought is promoted by encouragement and opportunities at an early age.

Although Lowenfield and Brittain (1975) argue that all children are born to be creative, many researchers believe that children are born with specific talents and abilities and the environment nurtures and develops these abilities. Warm supportive environments are highly correlated with creative potential in preschool children (Harrington, Block \& Block, 1987). Therefore, the conclusion is that nurture should be

emphasized more than nature. The question this raises is: What parts of the environment nurture creativity?

Many researchers disagree on the definition of creativity. However, most agree that creativity is a valuable asset that needs to be examined (Torrance, 1970). Lowenfield and Brittain (1975) 
believe the term creativity has become too widely used and the definition of creativity lies in the hands of who is doing the defining. Generally researchers think of fluency of ideas when defining creativity. Unfortunately, this provides a vague interpretation of creativity. The important aspects of creativity are the ability to produce "new" ideas, see "new" things and think "new" thoughts that are often overlooked. Preschool children were initially believed to be incapable of creative thinking. Over the years scientists have shown evidence that young children are creative and this "gift" is important to the child's healthy development (Torrance, 1981). For example, children demonstrate creativity by using their imagination to solve problems. This proves to be beneficial later in life in the areas of relationships, academics and even sports activities (Greenspan, 1994). Creative thinking is a powerful force that has brought about many great advances in technology. Due to the creativity of many early scholars there are such inventions as the automobile, airplane, television and radio (Torrance, 1965).

Creativity and intelligence are independent of one another. Often, creativity and intelligence are confused or thought to be the same quality. Torrance (1986) states that children have many strengths which are not usually measured in the educational system. Teachers and parents are concerned with I.Q. scores and test grades but tend to neglect creativity. Alfred Binet, known 
for his research of I.Q., urged teachers to continue to build on the skills that children have when they enter school (Torrance, 1981). These skills are generally creative ones such as imagining, storytelling, singing and dancing, as well as creating artistic products. Unfortunately, these skills are often thought to be a waste of time. Instead, there seems to be an urgency to start academic endeavors such as reading, writing and arithmetic.

In a study conducted by Fuchs-Beauchamp, Karnes and Johnson (1993) the relationship between creativity and intelligence in preschoolers was examined. The subjects were 227 boys and 219 girls between the ages of three and seven years old. The subjects were being tested for entry into a university program for gifted children. The Torrance Test of Thinking Creatively in Action and Movement was used to assess creativity. The Slosson Intelligence Test, The Stanford Binet Intelligence Scale and Binet Fourth Edition were used as intelligence measures. Findings of the study produced a significant relationship between creativity and intelligence when I.Q. was less than 120. No correlations were found for scores of 120 or more; these findings are consistent with other studies that have used older children and alternative measures. Unfortunately, researchers do not have a complete comprehension of the origin of children's creativity. Perhaps gifted children process information differently. Since the findings produce a small 
correlation between creativity and intelligence, it is possible that a nature/nurture connection arises, since I.Q. is believed to be innate and creativity is thought to be enhanced by a nurturing environment. Perhaps a child's natural ability to learn and the environment interact with one another to provide the most opportunistic creative experience for youngsters.

\section{The Effect of School on Creativity}

A major concern of Torrance (1981) has been the training of creativity in early childhood. In various studies conducted by Torrance (1962), a decline in creativity usually occurs when youngsters enter kindergarten. Preschool children between the ages of zero and five are believed to be in the peak period in which creativity can be nurtured (Dacey, 1989). Singer (1973) also reports findings of creative growth between the ages of three and five. Many abilities are emerging during the preschool years, and creativity happens to be one of them (Meador, 1992). Khatena (1971) believes that younger children are permitted to think in more creative directions, perhaps it is a luxury that is not permitted to older children. In other words, younger children are encouraged to enjoy life, whereas older children are encouraged to do well academically.

Thomas and Berk (1981) investigated the role of schooling in the development of creativity. A total of 225 children were 
studied. There were 126 boys and 99 girls, with 122 of the subjects being six-year olds and 103 being seven-year olds. Changes in creativity over a school year for first and second graders were examined for three types of school environments. The types were listed as informal, intermediate and formal. School types were determined by a ratings system. Raters used ten dimensions devised from Minuchin, Biber, Shapiro, and Zimiles's (1969) method of rating schools. An overall rating was determined by averaging the scores of descriptions that the raters evaluated from 1(very formal) to 7(very informal). The children were given Form A of the Torrance Thinking Creatively with Pictures and Form B, in the fall and spring of the school year respectively. No significant differences, among the three types of schools, were found in the scores of the creativity pretests. Pretest scores had to be used as a covariate in the analysis of variance due to significant negative correlations between pretest performance and the amount of growth between the two tests. The results suggest a complex relationship between schooling and the development of creativity. Type of school, sex of the child and the specific creative ability that was being assessed (fluency, flexibility and elaboration) played a part in the assessment. Children in intermediate schools scored higher on creativity scales, as opposed to children in formal schools. Oddly, children in informal schools did the best on some scales, which 
contradicts the hypothesis. Results suggest intermediate and informal environments were correlated highly with more growth over the school year. Girls were found to be more sensitive to school environments than boys. Creativity relationships proved to be difficult to predict. The hypothesis that intermediates schools would score higher than formal schools was supported, however, the fact that informal school children scored the best overall was not hypothesized.

\section{Creativity and Play}

Pretense is a child's way of detaching from the external environment and emotional concerns (Fein, 1981). However, to detach oneself, the conditions must be favorable to the child. Children detach more easily whenever they are free to explore and have fun. By detaching, or letting go of reality temporarily, children are free to explore "new" ideas and possibly "new" worlds. Researchers often refer to pretend play as: makebelieve, fantasy, imaginative or dramatic play (Garvey, 1977).

Play has been called the work of children (Meador, 1992). Many researchers agree that the most important product of play is the development of a child's imagination and creativity. It is essential to provide activities and situations that stimulate the imagination of children. An environment that is rich in play enables children to fantasize, make-believe and role play 
individually or with each other. During play, children interact by using objects, materials and their imagination. Singer (1973) describes imaginativeness of play as an aspect of creativity. By providing an opportunity for play a foundation for creativity is being constructed (Dansky \& Silverman, 1973).

Some research has provided evidence of a relationship between play and creativity. When conducting research with kindergartners, Liberman (1977) found that children who scored high on playfulness measures also scored high on divergent thinking measures. Dansky and Silverman (1975) found that children who were permitted to play with certain objects, later found more creative uses for them.

According to Dansky (1980), make believe play enhances creativity. Ninety-six preschool children were observed while engaged in make-believe play. Each child was then labeled as a "player" or a "non-player". Each subject was put in one of three situations involving objects: 1)make-believe or free play, 2) imitation of experimenter, or 3 ) problem solving. Free play was found to heighten fluency for the subjects labeled as "players". This implies that creativity can be enhanced by fantasy play. Play experiences during the preschool years prove to be beneficial to a child's creativity level. Once children enter the formal school system, play is often a neglected factor and the primary focus is on academics. 
Shmukler (1982-83) found that mothers who interfered with children's play were less likely to stimulate imagination in their

children. Whereas, mothers who initiated play, and permitted the child to go in his or her own direction, contributed more to the development of the child's imagination.

Singer and Singer (1985) believe children can develop their skills most efficiently with the initial help of adults, who then let the child go on his or her own. Of course encouragement is greatly needed from adults, but this should not be confused with intervention. This does not mean that children cannot play with adults, however, it is important for the adult to remember that they are there to go along with the child's ideas. Playing with children should not be thought of as a "chore" but the opportunity to experience the emotional rewards for fostering creativity in a child (Singer \& Singer, 1985).

\section{Creativity and Parental Influence}

Although research investigating creativity and parental involvement is scarce, it is known that parental encouragement is important to the development of creativity in preschoolers (Meador, 1992). Especially since the preschool years are so impressionable on youngsters (Torrance, 1962). Lowenfield and Brittain (1987) stress that self-worth influences a child's creative 
process, therefore it is important that parents help promote autonomy and provide support for youngsters.

Clay (1996) investigated the effects that parental influence had on preschoolers' creativity levels. It was hypothesized that parents' scores on The Parent As A Teacher (PAAT) would significantly predict children's scores on The Torrance Test of Thinking Creatively in Action and Movement (TCAM). However, this was not evident in the results, which found no relationship between the PAAT and the TCAM scores. This was not consistent with a previous study done by Strom, Hathaway and Slaughter (1981), which found a significant effect of parental influence on creativity in preschoolers. Clay (1996) also ran multiple regressions for the parental scores, with the additional variables of gender of the child, educational level of the parents, occupation of the parents, number of hours the parents worked outside of the home and the number of hours the parents spent with the child. None of these variables were significant in predicting the child's creativity score.

Rimm (1994) believed the home is the first laboratory of learning. She stressed the importance that parental interaction has on a child's learning experiences. Imaginative play can be incorporated into family time, as well as individual time for the child. Numerous opportunities for creative play are located in the kitchen, bathroom, bedroom, yard and any other place that 
one can use his or her imagination. It is important for parents to realize that they are the most important teachers (Rimm, 1994). Through love and learning children are given the opportunities they need to lead a successful life.

The creativity level of children can be linked to the family background and parent-child relations (Miller \& Gerard, 1979). Numerous factors such as gender, birth order, SES and parental relationships tend to contribute to a child's creativity level. Miller and Gerard (1979) found that younger children tend to be less creative whenever they are not close in age to their siblings. Social class differences in families also produce differences in creativity levels of youngsters. Parents of creative children tend to be more secure and competent. This seems to produce a supportive, respectful atmosphere for children.

\section{Socio-Economic Status (SES) Implications}

Smilansky (1968) investigated the effects of play on culturally disadvantaged children. Sociodramatic play of advantaged and disadvantaged children was researched using the five categories of: play themes and roles, use of toys and objects, verbalization during play, behavior of the leader of play and how problems were handled. It was found that very few of the disadvantaged children engaged in sociodramatic play. Adult roles were less elaborated in the play of the lower SES group, as 
compared to the play of the higher SES group. Toys were very important to the play of the lower SES group, but had little importance for the higher SES group. Leadership was shared in the higher SES group, but was authoritarian in the lower SES group. Problems were handled better by the higher SES group, and often led to the termination of play in the lower SES group.

In a study conducted by Rubin, Maioni, and Hornung (1976) strong social class differences were evident in the play behavior of preschoolers. The subjects were 23 boys and 17 girls, with a mean age of 3.87 for the middle-class children and 3.88 for the lower-class children. For 30 days each child was observed for 1 minute during the scheduled hour of free play. The observations were made with recorders behind a one-way mirror, in order to prevent disruptions. A checklist was used to record the form of cognitive play within each of the social play categories. Social play consisted of solitary, parallel, associative, cooperative and unoccupied/onlooker. Cognitive play consisted of functional, constructive, dramatic and games. Means were found for each of the categories of social and cognitive play. Then social and cognitive play were combined and means and percentages were found. Definitions for social play were based on Parten(1932) and cognitive play definitions were taken from Smilansky (1968). In the independent analysis of social and cognitive play, middleclass preschoolers had higher levels for constructive, associative 
and cooperative play. Whereas, lower-class preschoolers had higher levels of parallel and functional play. Females were more constructive and less dramatic than males. When social and cognitive play categories were combined, significant effects were found. Lower-class preschoolers had higher levels of solitaryfunctional and parallel-functional play, however, they had lower levels of associative-constructive, and cooperative-dramatic play, as opposed to middle-class preschoolers. Males scored higher in solitary-functional and associative-dramatic play but scored considerably lower than females on solitary-constructive and parallel-constructive play. These results provide evidence for social class differences in the play behavior of preschoolers. This is important to note since research provides a basis for a link between creativity and play of preschoolers.

Past research suggests that socioeconomic status plays an important role in the development of preschoolers. Children from lower socioeconomic status tend to play differently and place more importance on toys and solitary play, whereas children from higher socioeconomic status place less importance on toys and tend to incorporate play themes and organize their play. 


\section{Summary}

As indicated in the literature reviewed, creativity is a "gift" that needs to be nurtured in order to reach the greatest potential. Of course, some children are destined to be more creative than others, but all children deserve to have an enriched early childhood that establishes a foundation for creative potentialities.

Environment has been determined to be a main contributor to creativity levels in children (Torrance, 1965). Daugherty (1995) believes that early intervention is needed to nurture and enhance creative ability. Children have a natural drive to investigate their surroundings; however, learning depends on what the environment provides for investigation. Parents, teachers and peers provide intellectual and social stimulation that perhaps can prove to be beneficial for a child's life time (Lowenfield \& Brittain, 1975).

Social class must be taken into consideration in order to assess the affect that it has on the preschooler's creativity level and the mother's attitude assessment, if any. Strom (1978) noted a significant difference between upper-and lower-class mothers on items in the Parent As A Teacher Inventory (PAAT). The Hollingshead Four Factor Index of Social Status has been used to determine socio-economic status. 


\section{Purpose of this Study}

The purpose of this study was to investigate the influence that mothers have on the creativity level of preschool children. The Torrance Test of Thinking Creatively in Action and Movement (TCAM) was administered to measure the creativity level of the child participants. The Parent As A Teacher Inventory (PAAT) was used to measure maternal attitudes towards creativity. The study hypothesized that mother PAAT scores would be positively correlated with children's scores on the TCAM. Hypotheses were also developed for each of the three subtests of the TCAM and the five subtests of the PAAT.

The hypotheses for the TCAM subscales and socioeconomic status were as follows:

a) TCAM fluency scores will be positively related to socioeconomic status.

b) TCAM originality scores will be positively related to socioeconomic status.

c) TCAM imagination scores will be positively related to socioeconomic status.

The hypotheses for the PAAT subscales and socioeconomic status were as follows: 
a) PAAT creativity scores will be positively related to socioeconomic status.

b) PAAT frustration scores will not be positively related to socioeconomic status.

c) PAAT control scores will not be positively related to socioeconomic status.

d) PAAT play scores will be positively related to socioeconomic status.

e) PAAT teaching/learning scores will be positively related to socioeconomic status.

The hypotheses for the TCAM and the PAAT subscales were as follows:

a) TCAM fluency scores will be positively related to PAAT creativity scores.

b) TCAM fluency scores will not be positively related to PAAT frustration scores.

c) TCAM fluency scores will not be positively related to PAAT control scores.

d) TCAM fluency scores will be positively related to PAAT play scores.

e) TCAM fluency scores will be positively related to PAAT teaching/learning scores. 
f) TCAM originality scores will be positively related to PAAT creativity scores.

g) TCAM originality scores will not be positively related to PAAT frustration scores.

h) TCAM originality scores will not be positively related to PAAT control scores.

i) TCAM originality scores will be positively related to PAAT play scores.

j) TCAM originality scores will be positively related to PAAT teaching/learning scores.

k) TCAM imagination scores will be positively related to PAAT creativity scores.

1) TCAM imagination scores will not be positively related to PAAT frustration scores.

m) TCAM imagination scores will not be positively related to PAAT control scores.

n) TCAM imagination scores will be positively related to PAAT play scores.

o) TCAM imagination scores will be positively related to PAAT teaching/learning scores. 


\section{CHAPTER THREE}

\section{$\underline{\text { Methods }}$}

\section{Subjects}

The study consisted of 52 children, aged three to six years old, who attended one of the following preschools: Monongalia County Head Start, Pleasant Day Schools, METC Kids, Inc., or Scott's Run Settlement House Preschool. Twenty-two subjects were from Pleasant Day Schools, seventeen were from Monongalia County Head Start, ten from Scott's Run Settlement House and three were from METC Kids, Inc. Of the 52 subjects, 29 were males and 23 were females. Monongalia County Head Start children attend four days a week and follow the same schedule as Monongalia County Public Schools. Pleasant Day Schools, Scott's Run Settlement House Preschool and METC Kids Inc., attend five days a week throughout the year, excluding holidays. The specific sites were chosen in order to obtain an economically diverse group of individuals. Head Start is generally offered to disadvantaged families and provides training for parents to enrich the environment of their children. Scott's Run Settlement House also consisted primarily of lower income families. Pleasant Day Schools is an all-day day care, with a population that is economically diverse. Social class differences ranged from lower-middle to upper-middle class status. METC 
Kids, Inc. is a corporate day care drawing from upper-middle to upper class families. By using four schools, it was possible to obtain a population that varied in marital status, educational levels and occupations, which was needed in order to determine socioeconomic status using the Hollingshead Four Factor Index of Social Status.

\section{Measures}

\section{Torrance Test of Thinking Creatively in Action and Movement}

\section{$\underline{(\text { TCAM })}$}

The 1981 Torrance Test of Thinking Creatively in Action and Movement (TCAM) was used to assess the creativity level of the children. (See Appendix F.) The TCAM is an assessment tool that is designed to be used with three to eight year old children. The activities that are administered assess the creative thinking abilities of preschool children (Torrance, 1981). Four activities of the TCAM provide scores for imagination, fluency and originality. The scores for fluency, originality and imagination are averaged in order to obtain a total score. There are guides for converting raw scores to standard scores depending on the age of the child.

Activity One (How many ways?)

Activity one was designed to measure the young child's ability to produce alternative ways of moving. This activity was 
scored in the fluency and originality categories. The fluency score was calculated by the number of ways the child showed or described movement across the floor. The originality score was determined by comparing the child's response with that of ones listed in the testing manual. If a response was given but not listed, a score of three points was given. Bonus credit of four points was granted if two or more actions were combined to make one single action.

Activity Two (Can you move like?)

This activity was designed to assess the child's ability to imagine, fantasize, empathize and role play. This activity was scored for imagination. The child was to pretend that they were: a tree, a rabbit, a fish, a snake, driving a car, and trying to push an elephant off a desired object. A five point scale was used to score this activity. The overall imagination score was figured by adding the six separate ratings.

\section{Activity Three (What other ways?)}

Activity three was designed to measure the invention of new or unusual ways of performing simple everyday tasks. This activity was scored the same as activity one, for fluency and originality. The fluency score was the number of different ways that the child gave for getting a paper cup into a wastebasket. The originality score was determined by comparing the child's response with that of the ones given in the testing manual. Once 
again three points were given if a response was not listed and four points for choreographed actions.

\section{Activity Four (What might it be?)}

This activity was used to measure the ability of children to use objects for purposes other than they were intended. Fluency and originality were scored for this activity. The fluency score was the number of different uses for a paper cup that a child could think of. A list was provided to compare responses for computing the originality score. Responses that were not listed earned three points and four bonus points were given when applicable, as in activities one and three.

\section{$\underline{\text { Total Score }}$}

After scoring for the four activities was completed, the overall scores for fluency, originality and imagination were computed. The manual stated that each child would be given three scores. This resulted in a score for the three categories of fluency, originality and imagination. An overall averaged score of the three categories was used to get one overall TCAM score.

With careful use of the scoring guide in the manual, interscorer reliability of the Torrance Tests of Creative Thinking is greater than .90 (Torrance, 1981). Bolen (1976) obtained a reliability coefficient of .96 and no significant mean differences when he used a sample of second graders. Coefficients of .99 and .97 were obtained for fluency and originality, respectively, 
when the author's research assistant rescored eighteen records. Torrance and a research assistant found coefficients of .99 for fluency and .98 for originality, with no significant mean difference, for a sample of fifty records.

Overall test-retest reliability was between .58 and .79 for a group of twenty children ages three to five, who were tested two weeks apart (Torrance, 1981). It is important to score overall creative potential because children might be more "warmed" up the second time they take the test and show more excitement in the beginning and become bored or tired in the later activities or perhaps have the opposite effect of boredom and then "warm" up or feel more relaxed toward the end of the test. Therefore, individual activity scores could provide lower test-retest reliability.

A validity study of the TCAM and Piagetian conservation, the modified Piaget, and mathematics readiness was conducted with a sample of thirty-four preschool children. It was found that the TCAM scores correlated .02 with Piagetian conservation, .58 with the modified Piaget, and .57 with mathematics readiness. Piagetian tasks in divergent problem solving show a higher correlation with the TCAM than those of Piagetian tasks in convergent thinking (Torrance, 1981). 


\section{Parent As A Teacher Inventory (PAAT)}

The Parent As A Teacher Inventory (PAAT) was used to record maternal attitudes toward creativity. (See Appendix E.) The PAAT is not a test, it is more of an attitude assessment. Parents are asked to describe their feelings about certain topics such as play, creativity, frustration, control and teaching/learning. The PAAT helps mothers and fathers of children between the ages of three to nine identify what they feel are important qualities and provides insight into areas in which the parent needs to provide more stimulation (Strom, 1984). It is an individualized process since each parent receives an individual profile. There were four answers that a parent could chose from on the PAAT. They were as follows: "strong yes", "yes", "no" or "strong no". Strong answers were only encouraged when a parent had absolutely no doubt in his or her mind. The PAAT scoring manual directed the respondent to assign a value of $1,2,3$, or 4 to each one of the 50 items. When values were assigned to each answered item, subtotals for the subtests were obtained. Strom (1984) relied on two forms to test the reliability of the PAAT. Those two forms were listed as Form A and Form B. When Form A was administered to 124 parents, who had fouryear olds, there was a coefficient alpha of .76 for the sample; whereas, Form B produced an internal reliability of .83 for a sample of mothers of second graders. 


\section{Hollingshead Four Factor Index of Social Status}

The Four Factor Index of Social Status was used in order to assess the socio-economic status of the participants. The four factors were: marital status, retired persons, educational factor and occupational factor. Therefore, socio-economic status was determined by the maternal questionnaire. This proved to be a less intrusive way to obtain social class, as opposed to asking specific income questions. Major business and professional social strata scores range from 55-66. Medium business, minor professional and technical social strata scores range from 40-54. Skilled craftsman, clerical and sales workers scores range from 30-39. Machine operators and semiskilled workers scores range from 20-29. Unskilled laborers and menial service workers scores range from 8-19.

\section{Procedure}

A letter that outlined the study was distributed to the children by the preschool teacher. A maternal consent form was included with the letter. It was requested that the mothers return the consent letter within three days. After collecting the consent forms the researcher took the forms from the mothers whom consented and assigned each one a different number. The participants were then given the corresponding number with the consent form and assigned a lower case "m" to males and a lower 
case "f" for females. The TCAM and the PAAT were coded with each child's number and letter after all of the required information was obtained. This information was only known by the researcher to insure participant privacy and discourage biases. The children were then given an information form and the PAAT questionnaire to take home to the mothers. The mothers were asked to fill out the form and questionnaires and return them to school with their child. It was requested that the forms be returned within four days. Meanwhile the testing of the participants began. The researcher, went to the appropriate schools, and administered the TCAM to the children for whom maternal consent was obtained. 


\section{CHAPTER FOUR}

\section{$\underline{\text { Results }}$}

\section{Inter-Rater Reliability}

Correlations were run in order to determine inter-rater reliability for the two raters. For the fluency subscale of the TCAM a correlation of $\underline{\mathrm{r}}=.81$ was obtained. The originality and imagination subscales had correlations of $\underline{r}=.93$ and $\underline{r}=.97$ respectively (See Table 1.) The main rater's scores were used in the statistical analysis of the results. However, as one can see from the correlations the raters' perceptions were very similar.

\section{Table 1}

\section{Inter-Rater Reliability Correlations}

\section{Means and Standard Deviations}

Analyses were run for each of the subscales and the overall scores of the TCAM and the PAAT. (See Table 2.) 


\section{Table 2}

\section{Means and Standard Deviations of Variables}

\begin{tabular}{l|ll}
$\mathbf{N}=52$ & & \\
Variable & Mean & Standard Deviation \\
\hline TCAM Fluency Rater 1 & 80.269 & 10.672 \\
TCAM Originality Rater 1 & 68.692 & 29.908 \\
TCAM Imagination Rater 1 & 71.288 & 22.865 \\
TCAM Fluency Rater 2 & 80.788 & 13.792 \\
TCAM Originality Rater 2 & 70.577 & 28.441 \\
TCAM Imagination Rater 2 & 72.519 & 24.010 \\
Socioeconomic Status(SES) & 34.413 & 12.038 \\
PAAT Creativity & 29.615 & 3.402 \\
PAAT Frustration & 28.462 & 2.900 \\
PAAT Control & 27.731 & 3.526 \\
PAAT Play & 30.827 & 2.542 \\
PAAT Teaching/Learning & 30.673 & 2.909 \\
Total TCAM & 220.250 & 49.003 \\
Total PAAT & 147.308 & 9.948
\end{tabular}

The mean scores and standard deviations for fluency, originality and imagination were: $80.3(\mathrm{SD}=10.7), 68.7(\mathrm{SD}=29.9)$ and $71.3(\mathrm{SD}=22.9)$, respectively. The mean and standard deviation for the overall TCAM was $220.3(\mathrm{SD}=49.0)$. (See Table 2.) The mean scores and standard deviations 
for the PAAT creativity, frustration, control, play and teaching/learning were: $29.6(\mathrm{SD}=3.4) ; 28.5(\mathrm{SD}=2.9) ; 27.7(\mathrm{SD}=3.5) ; 30.8(\mathrm{SD}=2.5)$ and $30.7(\mathrm{SD}=2.9)$, respectively. The mean score and standard deviation for the overall PAAT was $147.3(\mathrm{SD}=9.9)$. (See Table 2).

\section{Main Hypothesis}

This study hypothesized that the mother overall PAAT Scores would be positively correlated with the child overall TCAM Scores. Pearson Product Moment Correlations were run to determine the relationship between the mother overall PAAT scores and the child overall TCAM scores. Analyses indicate that the overall PAAT scores and the overall TCAM scores were not correlated $(\underline{\mathrm{r}}=.19, \underline{\mathrm{p}}<.19$.

\section{Correlations Between the PAAT and the TCAM Subscales}

Pearson Product Moment Correlations were run between the PAAT and TCAM subscales. TCAM fluency was positively related to PAAT control $(\underline{\mathrm{r}}=.29, \underline{\mathrm{p}}<.04)$ and PAAT frustration $(\underline{\mathrm{r}}=.28, \underline{\mathrm{p}}<.05)$. TCAM originality was also correlated with the PAAT subscales of control ( $\underline{r}=.46$, $\underline{\mathrm{p}}<.001)$ and frustration $(\underline{\mathrm{r}}=.35, \underline{\mathrm{p}}<.01)$. The PAAT subscales of creativity, 
play and teaching/learning did not have a relationship with any of the three TCAM subscales. There were no corrleations between TCAM imagination and the PAAT subscales. (See Table 3.)

\section{Table 3}

Correlations between the TCAM and the PAAT Subscales

PAAT

\begin{tabular}{l|lllll} 
& Control & Creativity & Play & Frustration & Teach/Learn \\
\hline TCAM & & & & & \\
\hline \multirow{2}{*}{ Fluency } & .286 & .162 & .013 & .276 & -.167 \\
Imagination & $(.04)^{*}$ & $(.251)$ & $(.925)$ & $(.05)^{*}$ & $(.237)$ \\
& .463 & .202 & -.029 & .353 & -.158 \\
& $(.0006)^{* * *}$ & $(.151)$ & $(.841)$ & $(.01)^{* *}$ & $(.265)$ \\
-.006 & -.156 & -.032 & .108 & -.095 \\
& $(.967)$ & $(.271)$ & $(.821)$ & $(.447)$ & $(.503)$
\end{tabular}

$P$-Values in parentheses

$* \mathbf{p}<.05$

$* * \mathbf{p}<.01$

$* * * \mathbf{p}<.001$ 


\section{$\underline{\text { SES (Socioeconomic Status) Results }}$}

SES was determined by the Hollingshead Four Factor Index of

Social Status. The mean score for SES was 34.41. Out of the 52 subjects:

3 were in the major business and professional strata; 15 were in the medium business, minor professional and technical strata; 18 were in the skilled craftsmen, clerical and sales workers strata; 8 were in the machine operators and semiskilled workers strata and 8 were in the unskilled laborers and menial service workers strata. The goal of obtaining a heterogeneous population was achieved.

It was hypothesized that families from the higher socioeconomic strata would produce higher TCAM and PAAT subscale scores except for control and frustration, which would be lower. Pearson Product Moment Correlations were conducted to determine the relationship between SES and the subscale scores. Consistent with a previous study conducted by Strom (1984), the overall PAAT scores $(\underline{r}=.40, \underline{p}<.003)$ and the PAAT creativity scores $(\underline{r}=.41, \underline{p}<.003)$ were positively correlated with socioeconomic status. The PAAT control scores were also correlated with $\operatorname{SES}(\underline{r}=.37, \underline{p}<.01)$. (See Table 4.) 


\section{Table 4}

Correlations of the TCAM and PAAT Subscales with SES

\begin{tabular}{l|ll} 
Variable & $|\mathbf{r}|$ & P-Value \\
\hline TCAM Fluency & .182 & .196 \\
TCAM Originality & .188 & .181 \\
TCAM Imagination & .049 & .733 \\
PAAT Creativity & .407 & $.003^{*}$ \\
PAAT Frustration & .180 & .202 \\
PAAT Control & .356 & $.010^{*}$ \\
PAAT Play & .215 & .125 \\
PAAT Teaching/Learning & .082 & .563 \\
Total TCAM & .177 & .209 \\
Total PAAT & .397 & $.004^{*}$
\end{tabular}

Parents from higher social strata valued creativity and control. This is inconsistent with previous studies. Strom (1984) reported that mothers from lower socioeconomic strata scored higher in the control subscale. It is assumed that mothers from higher socioeconomic strata would encourage creativity and would tend to be less controlling in order to not suppress the development of creativity. However, this study found 
significant effects concerning SES and the PAAT control scores. The remaining PAAT subscales of frustration $(\underline{r}=.18, \underline{p}<.20)$, play $(\underline{r}=.22$, $\underline{\mathrm{p}}<.12)$ and teaching/learning $(\underline{\mathrm{r}}=.08, \underline{\mathrm{p}}<.56)$ were not correlated with SES.

The correlation between SES and the TCAM subscale scores of fluency $(\underline{\mathrm{r}}=.18, \underline{\mathrm{p}}<.20)$; originality $(\underline{\mathrm{r}}=.19, \underline{\mathrm{p}}<.18)$; imagination $(\underline{\mathrm{r}}=.05$, $\underline{p}<.73)$ and overall $(\underline{r}=.18, \underline{p}<.21)$ were also non-significant. (See Table 4.) Miller and Gerard (1979) found positive correlations between SES and children's verbal creativity, which is contrary to our findings.

For purposes of data analysis a median split was performed, producing 26 designated as the higher social strata and 26 as the lower social strata. The median split was at the score of 35 , which falls into the category of skilled craftsman, clerical and sales workers for the Hollingshead analysis. The higher social strata had a minimum score of 35 and a maximum score of 61 . The lower social strata had a minimum score of 14 and a maximum score of 34 .

Eight one-way ANOVAs were run with the SES median split, to determine if there was any influence on the three subscales of the TCAM and the five subscales of the PAAT. Two additional one-way ANOVAs were also conducted to examine the influence of SES on the overall TCAM and overall PAAT scores. 
Mothers from higher socioeconomic strata exhibited higher scores on the PAAT overall, $\underline{\mathrm{F}}(1,51)=9.36, \mathrm{p}<.004$. It was determined that the PAAT creativity scores, $\underline{F}(1,51)=9.93$, $\mathrm{p}<.003)$, had significant SES effects. In addition, the ANOVA revealed a significant effect of SES on the PAAT control subscale, $\underline{F}(1,51)=7.28, \underline{p}<.01$. There were no significant SES effects with the PAAT frustration, play and teaching/learning scores with $\underline{F}(1,51)=1.68, \underline{\mathrm{p}}<.202 ; \underline{\mathrm{F}}(1.51)=2.43, \underline{\mathrm{p}}<.125 ;$ $\underline{F}(1,51)=.34, \underline{p}<.563 ;$ respectively. (See Table 5.$)$ These findings support those of the Pearson Product Moment Correlation analyses.

Further, there were no significant effects of SES on the TCAM overall subscale, $\underline{F}(1,51)=1.62, \underline{p}<.209$. The TCAM fluency, originality and imagination subscales were also not significant with: $\underline{\mathrm{F}}(1,51)=1.72, \underline{\mathrm{p}}<1.96 ; \underline{\mathrm{F}}(1,51)=1.84, \underline{\mathrm{p}}<.181$ and $\underline{F}(1,51)=.120, \underline{p}<.733 ;$ respectively. (See Table 6.) These findings also support the Pearson Product Moment Correlation findings. 
Table 5

Analysis of Variance (ANOVA) for the PAAT Creativity, PAAT Frustration, PAAT

Control, PAAT Play and PAAT Teaching/Learning Subscales

\begin{tabular}{l|lllllll}
$\begin{array}{l}\text { PAAT } \\
\text { Subscale }\end{array}$ & DF & F-Value & P-Value & $\begin{array}{l}\text { High } \\
\text { Mean }\end{array}$ & $\begin{array}{l}\text { High } \\
\text { SD }\end{array}$ & $\begin{array}{l}\text { Low } \\
\text { Mean }\end{array}$ & $\begin{array}{l}\text { Low } \\
\text { Creativity }\end{array}$ \\
$\begin{array}{lllllll}\text { Frustration } \\
\text { Control }\end{array}$ & 51 & 1.68 & .202 & 28.54 & 2.34 & 28.38 & 3.42 \\
Play & 51 & 7.28 & $.010^{*}$ & 28.35 & 3.31 & 27.12 & 3.69 \\
Teach/Learn & 51 & 2.43 & .125 & 31.27 & 2.15 & 30.38 & 2.86 \\
& 51 & .34 & .563 & 30.77 & 2.66 & 30.58 & 3.19
\end{tabular}

Significant at $\mathbf{p}<.01$ 
Table 6

Analysis of Variance (ANOVA) for TCAM Fluency, TCAM Originality and TCAM

$\underline{\text { Imagination Subscales }}$

\begin{tabular}{l|ccccccc}
$\begin{array}{l}\text { TCAM } \\
\text { Scale }\end{array}$ & DF & F-Value & P-Value & High & High & Low & Low \\
Mean & & & & SD & Mean & SD \\
\hline Oruency & 51 & 1.72 & .196 & 81.31 & 9.72 & 79.23 & 11.65 \\
Imagination & 51 & 1.84 & .181 & 68.46 & 30.10 & 68.92 & 30.31 \\
& 51 & .20 & .733 & 73.12 & 22.21 & 69.46 & 23.80
\end{tabular}

A one-way ANOVA was run with the overall TCAM score and the overall PAAT score being the dependent variables and SES as the independent variable. The overall TCAM was not statistically significant, $\underline{F}(1,51)=1.62, \underline{p}<.209$. However, the overall PAAT was significant, $\underline{F}(1,51)=9.36, \underline{p}<.004$. Socioeconomic status (SES) had an influence on maternal scores, but not child scores. 


\section{CHAPTER FIVE}

\section{$\underline{\text { Discussion }}$}

\section{$\underline{\text { Socioeconomic Status Effects }}$}

This study assumed that SES would influence maternal attitudes and preschoolers' creativity levels. Some of the results are significant and suggest that SES does influence some maternal attitudes. The PAAT overall, control and frustration subscales had a relationship with SES. This is a major finding since maternal attitudes could ultimately affect the learning process of children. However, there were no results to support the role of SES directly on the creativity of the children using the TCAM. In addition there were few indirect effects of the mother's SES on the child. The results of this study were not consistent with those of Miller and Gerard (1979), where SES had significant effects on the creativity levels of school aged children. Social class was positively related to children's verbal creativity. Relationships between creative children and their parents were marked by respect, independence and freedom.

Smilansky (1968) investigated the effects of play on culturally disadvantaged children. It was found that very few of the disadvantaged children engaged in sociodramatic play. Adult roles were less elaborated 
in the play of the lower SES group and toys were very important to the play of the lower SES group. Whereas, the higher SES group was able to play without as much emphasis on toys. The present study was unable to find any significant SES differences in the PAAT play subscales. However, SES differences were found for the PAAT overall, creativity and control subscales.

Mothers might believe that preschool children need gentle direction to foster creativity, whereas older children tend to not be as easily distracted and could require less direction. Therefore, control may be exercised to direct children towards activities that would promote creative growth when they are younger.

Strong social class differences were evident in the play behavior of preschoolers in a study conducted by Rubin, Maioni and Hornung (1976). Middle-class preschoolers had higher levels of constructive, associative and cooperative play. Whereas, lower-class preschoolers had higher levels of parallel and functional play. These results provide evidence for social class differences in the play behavior of preschoolers. Although the present study focused on creativity and did not directly investigate play, creativity is demonstrated in the play of children. Nonetheless, there were no significant findings that SES influenced the creativity level of 
preschool children. Results indicated that SES did influence some maternal attitudes, specifically control.

In this study, as revealed by the Pearson's Product Moment Correlations, the PAAT overall, creativity and control subscales were positively correlated with SES. The one-way ANOVAs that were run provided additional support. Strom (1984) reported significant SES effects on the PAAT overall and creativity subscales. In this study, the significant SES effects on the PAAT control subscale were not expected. A possible explanation could be that mothers from higher socioeconomic strata exert control in order to promote creative growth in preschool children.

\section{Parental Influence}

The primary purpose of this study was to investigate maternal attitudes as measured by the PAAT and the creativity levels of preschool children as measured by the TCAM. It was assumed that, if a mother valued creativity highly, then her child would be more inclined to score higher on the TCAM, as opposed to a child whose mother did not regard creativity as highly. 
Clay (1996), using preschool children, hypothesized that parents' scores on The Parent As A Teacher (PAAT) would significantly predict children's scores on The Torrance Test of Thinking Creatively in Action and Movement (TCAM). She found that parental attitudes were not correlated with the creativity levels of the preschool children, which the author attributed to the small sample size, which was limited to one preschool. The present study was able to obtain a larger population by using various schools to obtain subjects. However, in spite of this, there were no correlations between the TCAM and the PAAT. This is the same finding as in the Clay (1996) study, which suggests that this relationship might not occur in preschool children.

\section{Limitations of the Study}

Head Start is primarily for the children of disadvantaged families. Monongalia County Head Start was chosen for this study in order to obtain subjects that fall into a lower socioeconomic status. However, Head Start has guidelines, which requires that parents receive training on developmentally appropriate child rearing practices. This could have compromised the results of this study since these mothers could have been educated, therefore, regarding creativity and play as valuable attributes. 
The results of this study may have been compromised by the fact that lower SES mothers tended to answer more items with "strong" answers on the PAAT. Whereas, higher SES mothers tended to answer more items without the "strong" emphasis. It was as if the lower SES mothers anticipated what would be the "correct" answer and felt obligated to answer the "best" that they could. These mothers may have considered the attitude assessment a "test" instead of an attitude assessment. On the other hand, the higher SES mothers appeared to try to put more thought into obtaining an answer. This may have had an effect on the results of the study.

Another problem could be the fact that the mothers had the right to review the Thinking Creatively in Action and Movement (TCAM) assessment before the testing. Mothers could have anticipated what was expected of the children and had an opportunity to coach them. This might have affected the results of the creativity test.

\section{Study Contributions}

This study found no significant effects between parental influence and child creativity. This is consistent with the findings of Clay (1996). 
Where no significant relationship was found between the TCAM scores and the parent PAAT scores.

Miller and Gerard (1979) found significant effects of SES on the creativity level of school aged children. The present study was unable to report any significant SES effects on the creativity level of preschool children. Socioeconomic status effects might not take effect as early as the preschool years. Therefore, age is a variable that could produce differing effects for SES.

SES was found to significantly influence maternal attitudes in the areas of creativity, control and the overall PAAT. Mothers might believe that preschool children need gentle direction to foster creativity, whereas older children tend to not be as easily distracted and could require less direction. Therefore, control may be exercised to direct children towards activities that would promote creative growth when they are younger.

This study suggests that SES can affect maternal attitudes, which in turn could affect the development of preschool children. This study proves that there is a need for future research to investigate preschooler's creativity and parental influence. Perhaps, with more research in this area, parents will be more educated as to the effect that they can have on the creativity level of their child. More research in the area of SES could 
produce significant results, which could lead to enhanced programs for disadvantaged preschoolers.

Parents need to understand the influence that they have in their child's life. All aspects, not just creativity, of a preschooler's development are positively or negatively influenced by their environments. It is essential to nurture what a child has been blessed with at birth.

\section{Future Research}

Since we suggested that SES effects could differ with age, future research with children of all ages could produce significant results. Perhaps a longitudinal study would be able to produce significant results between SES and age.

Another suggestion would be to stress to the parents that the attitude assessment is just that. Explain more in depth that they are not being "graded" on their parental skills, but just being surveyed about their attitudes. As for the parental review of the creativity test (TCAM), it is their right to review the test that will be given to their child. Perhaps, it may also be beneficial to observe the mother interacting with her child in a 
play situation. Comparisons could be made with the observation and the answers the mother had on the Parent As A Teacher (PAAT).

Additionally, studies investigating parental control and creativity could produce significant results. The relationship between socioeconomic status and control also appears to be worthy of future research. Perhaps additional findings could support those of this study, which indicates that SES is positively related to parental control. 


\section{BIBLIOGRAPHY}

Beatty, B. (1995). Preschool education in America: The culture of young children from the colonial era to the present. New York: Vail Ballou Press.

Clay, C. (1996). An examination of parental influence on the creativity of preschoolers. Unpublished master's thesis. West Virginia University, Morgantown, West Virginia.

Dacey, J. (1989). Peak periods of creative growth across the lifespan. The Journal of Creative Behavior, 23 (4), 224-247.

Dansky, J. (1980). Make-believe: A mediator of the relationship between play and associative fluency. Child Development, 51, 576-579.

Dansky, J. \& Silverman, I. (1973). Effects of play on associative fluency in preschool-aged children. Developmental Psychology, 9(1), $38-43$.

Dansky, J. \& Silverman, I. (1975). Play: A general facilitator of associative fluency. Developmental Psychology, 11 (1), 104.

Dansky, J. \& Silverman, I. (1980). Make-believe: A mediator of the relationship between play and associative fluency. Child Development, 51, 576-579. 
Daugherty, M., White, C.S., \& Manning, B.H. (1995). Private speech and creativity. Contemporary Educational Psychology, 20, 222229.

Fein, G. (1981). Pretend play: An integrative review. Child Development, 52, 1095-1118.

Feitelson, D., \& Ross, G. (1973). The neglected factor-play. Human Development, 16, 202-223.

Fuchs-Beauchamp, K.D., Karnes, M.B., \& Johnson, L.J. (1993). Creativity and intelligence in preschoolers. Gifted Child Quarterly, 37 (3), 113-117.

Garvey, C. (1990). Play. Cambridge, M.A.: Harvard University Press.

Greenspan, S.I. (1994). Building creativity. Parents, December, 87-88.

Harrington, D.M., Block, J., \& Block, J.H. (1983). Predicting creativity in preadolescence from divergent thinking in early childhood. Journal of Personality and Social Psychology, 45 (3), 609-623.

Harrington, D.M., Block, J., \& Block, J.H. (1987). Testing aspects of Carl Roger's theory of creative environments: Child-rearing 
antecedents of creative potential in young adolescents. Journal of Personality and Social Psychology, 52 (4), 851-856.

Hollingshead, A.B. (1975). Four factor index of social status. Unpublished working paper, Yale University.

Khatena, J. (1971). Teaching disadvantaged preschool children to think creatively with pictures. Journal of Educational Psychology, 62 (5), 384-386.

Lieberman, J. (1965). Playfulness and divergent thinking: An investigation of their relationship at the kindergarten level. Journal of Genetic Psychology, 107, 219-224.

Lieberman, J. (1977). Playfulness: It's relationship to imagination and creativity. New York: Academic Press.

Lowenfield, V. \& Brittain, W.L. (1975). Creative and mental growth. New York: Macmillian.

Maxim, G. (1989). The very young child: Guilding children from infancy through the early years. (3rd ed.). Ohio: Merrill.

Meador, K.S. (1992). Emerging rainbows: A review of the literature on creativity in preschoolers. Journal for the Education of the Gifted, 15 (2), 163-181. 
Miller, B.C., \& Gerard, D. (1979). Family influences on the development of creativity in children: An integrative review. The Family Coordinator. 28, 295-312.

Moran, J.D., Milgram, R.M., Sawyers, J.K., \& Fu, V.R. (1983).

Original thinking in preschool children. Child Development, 54, 921-926.

Moran, J.D., Sawyers, J.K., Fu, V.R., \& Milgram, R.M. (1984).

Predicting imaginative play in preschool children. Gifted Child Quarterly, $28,92-94$.

Moran, J.D., Sawyers, J.K., Fu, V.R., \& Milgram, R.M. (1988).

Measuring creativity in preschool children. Journal of Creative Behavior, 22, 254-263.

Parten, M. (1932). Social participation among preschool children. The Journal of Abnormal and Social Psychology, 27, 243-269.

Piaget, J. (1965). Play, dreams and imitation in childhood. New York: Norton.

Rimm, S.B. (1994). Keys to parenting the gifted child. New York: Barron's Educational Series, Inc.

Rosenthal, A. (1983). The creative child. Parents, April, 60-65. 
Rubin, K.H., Maioni, T.L., \& Hornung, M. (1976). Free play behaviors and lower-class preschoolers: Parten and Piaget revised. Child Development, 47, 414-419.

Shimm, P.H.\& Ballen, K. (1996). Boosting creativity. Parents. May. 88-90

Shmukler, D. (1982-83). Preschool imaginative play predisposition and its relationship to subsequent third grade assessment. Imagination, Cognition and Personality, 2 (3), 231-240.

Singer, J.L. (1973). The child's world of make-believe: Experimental studies of imaginative play. New York: Academic Press.

Smilansky, S. (1968). The effects of sociodramatic play on disadvantaged preschool children. New York: Wiley.

Strom, R., Hathaway, C., \& Slaughter, H. (1981). The correlation of maternal attitudes and preschool children's performance on the MC Carthy Scalles of Children's Abilities. Journal of Instructional Psychology, 8 (4), 139-145.

Strom, R., \& Slaughter, H. (1978). Measurement of childrearing expectations using The Parent As A Teacher Inventory. Journal of Experimental Education, 46, 44-53. 
Strom, R.D. (1984). Parent As A Teacher Inventory Manual.

Bensenville, IL: Scholastic Testing Service.

Sutton-Smith, B. (1967). The role of play in cognitive development. Young Children, 22, 361-370.

Tegano, D.W., Moran, J.D., \& Godwin, L.J. (1986). Crossvalidation of two creativity tests designed for preschool children. Early Childhood Research Quarterly, 1 (4), 387-396.

Thomas, N.G., \& Berk, L.E. (1981). Effects of school environments on the development of young children's creativity. Child Development, 52, 1153-1162.

Torrance, E.P. (1962). Guilding creative talent. Englewood Cliffs, N.J.: Prentice-Hall.

Torrance, E.P. (1965). Rewarding creative behavior. Englewood Cliffs, N.J.: Prentice-Hall.

Torrance, E.P, \& Myers, R.E. (1970). Creative learning and teaching. New York: Dodd, Mead \& Company.

Torrance, E.P. (1972). Predictive validity of the Torrance Tests of Creative Thinking. The Journal of Creative Behavior, 6 (4), 236-262. 
Torrance, E.P. (1981). Administration, Scoring and Norms Manual: Thinking Creatively in Action and Movement. Bensenville, IL: Scholastic Testing Service.

Torrance, E.P. \& Safter, H.T. (1986). Are children becoming more creative? Journal of Creative Behavior, 20, 1-13.

Trostle, S, \& Yawkey, T. (1983). Facilitating creative thought through object play. The Journal of Creative Behavior, 17 (3), 181-189.

Ward, W.C. (1968). Creativity in young children. Child Development, 39, 737-754.

Zimiles, R. (1986). Today's kindergarten: exploring the knowledge base, expanding the curriculum. New York: Teachers College Press. 
APPENDICES 


\section{$\underline{\text { APPENDIX A }}$}

PARENTAL/GUARDIAN CONSENT FORM 


\section{West Virginia University}

College of Agriculture, Forestry and Consumer Sciences

PARENTAL or GUARDLAN CONSENT and INFORMATION FORM

Maternal Attitudes and their Influence on the Creativity Level of Preschool Children

Introduction. have been asked to allow my child

WEST VRGINIS IFHVESITY

Institution Review Board tor the Protection of Human Research subjects

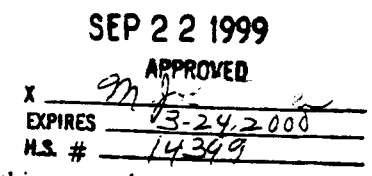

to participate in this suxdy. Kimberly Heilen, who is conducting this research to

fulfill the requirements for a master's thesis in Child Development and Family Studies at West Virginia

University, has explained the study to me.

Purposes of the Study. The purpose is to learn more about the creativity of preschool children.

Description of Procedures. This study will be performed at Pleasant Day Schools; Monongalia County Head Start, METC Kids Inc. and Scotts Rim Settiement House. My child will be asked to complete a motor test, which will take about 10-15 minutes to complete. I will be asked to fill out a 50 question questiomnaire and an information sheet. I have been given an opportunity to examine the questionnaire and test. Approximately 50 subjects will be entered in this study.

Risks and Discomforts. There are no known or expected risiks from participating in this study. The motor test is designed for children and is not intended to be difficult for my child.

Benefits. I understand that this study is not expected to be of direct benefit to my child, but the knowledge gained may be of benefit to others.

Contact Persons. For more information about this research, I can contact Kimberty Hellen at (304) 2936366 or her supervisor, Dr. Wanda Franz at (304) 293-3402.

For more information regarding wy child's rights as a research subject, I mry contact the Execurive Secretary of the Institutional Review Board at (304) 293-7073.

Confidentiality. I understand that any information obtained as a result of my chrld's participation in this research will be kept as confidential as legally possible. I understand that these research records, just like hospital records, may be subpoenaed by court order or may be inspected by federal regulatory authorities. My name or that of my child or any information from which we might be identified may not be published without my consent.

Volnntary Participation. Participation in this study is volumtary. I understand that I may withdraw my chiid from this study at any time. Refusal to participate or withdrawal will involve no penalty or loss of benefits for me or my child. I have been given the opportumity to ask questions abour the research, and I have received answers concerning areas I did not understand. Upon signing this form, I will receive a copy.

I willingly consert to my child's participation in this research.

Signature of Paremt or Guartian

Signature of Investigator or

Investigator's Representative
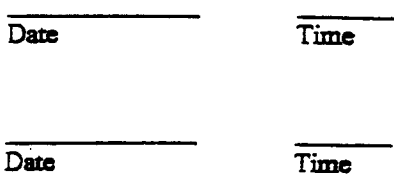
$\underline{\text { APPENDIX B }}$

INFORMATION LETTER 
West Virginia University

College of Agriculture, Forestry and Consumer Sciences

Dear Parent (s) or Guardian :

My name is Kimberly Hellen and I am a graduate student in the Department of Family and Consumer Sciences at West Virginia University. For my master's thesis I am studying maternal attitudes and preschoolers creativity levels. The study will be performed at Pleasant Day Schools, Monongalia County Head Start, METC-Kids, Inc. and Scotts Run Settlement House. This study will involve a maternal questionnaire and information sheet and a brief creativity motor test will be given to your child.

Your participation in this study is voluntary. Your privacy will be respected and your name and your child's name will not be used in the results of the study.

Please read through the attached consent form and sign it if you are interested in participating in the study. It would be greatly appreciated if you could return the form by October 8. Regardless of your choice to participate or not, if your form is returned within three days your child will receive a McDonald's coupon. If you do not wish to participate, simply do not sign the consent form and write your child's name on the top of it.

Please feel free to call me at (304) 293-6366 during the day or (724) 569-2331 in the evening, if your have any questions or concerns. You may also contact my academic advisor, Dr. Wanda Franz, at (304) 293-3402.

Upon completion of this study, I will gladly provide the results if you contact me. Once again, if you have any questions or concerns please contact me. Your participation in this study is greatly appreciated.

Sincereły,

WEST VIRGINIA UNIVERSTY Institution Review Board for the Protection of Human Research Suliects

SEP 221999

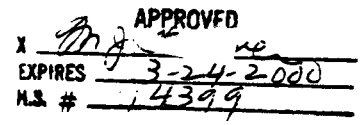

Kimberly Heiren

Graduate Student

West Virginia University

Dr. Wanda Franz

Professor/Academic Advisor

West Virginia University

$304293.3402=$ FAx 304 293-2750 = 702 Aller thall - 90 Box $0124=$ Morgantown WV 26506-6:24

Equal Doooriurily Affirmative Ac:ion Irstiturion 


\section{$\underline{\text { APPENDIX C }}$}

MATERNAL QUESTIONNAIRE 
1. Name:

2. Your Child's Name:

3. Your Child's Age:

4. Marital Status: (Please circle one) Married Single

5. Level of School Completed-Mother (Please circle one)

Seventh grade or lower

Jr. high school ( $9^{\text {th }}$ grade)

Some high school $\left(10^{\mathrm{A}}\right.$ or $11^{\mathrm{A}}$ grade)

High school graduate

Some college

College graduate

Graduate degree

6. Level of school completed -Spouse

*If you answered "single" for Question \#4 please skip this question and go to Question \#7

Seventh grade or lower

Jr. high school ( $9^{*}$ grade)

Some high school $\left(10^{\mathrm{s}}\right.$ or $11^{\mathrm{t}}$ grade)

High school graduate

Some College

College graduate

Graduate Degree

7. Mother's Occupation:

8. Spouse's Occupation:

*Please skip this question if you answered "single" to Question \#4

Thank You! 


\section{$\underline{\text { APPENDIX D }}$}

\section{PARENT AS A TEACHER INVENTORY (PAAT)}




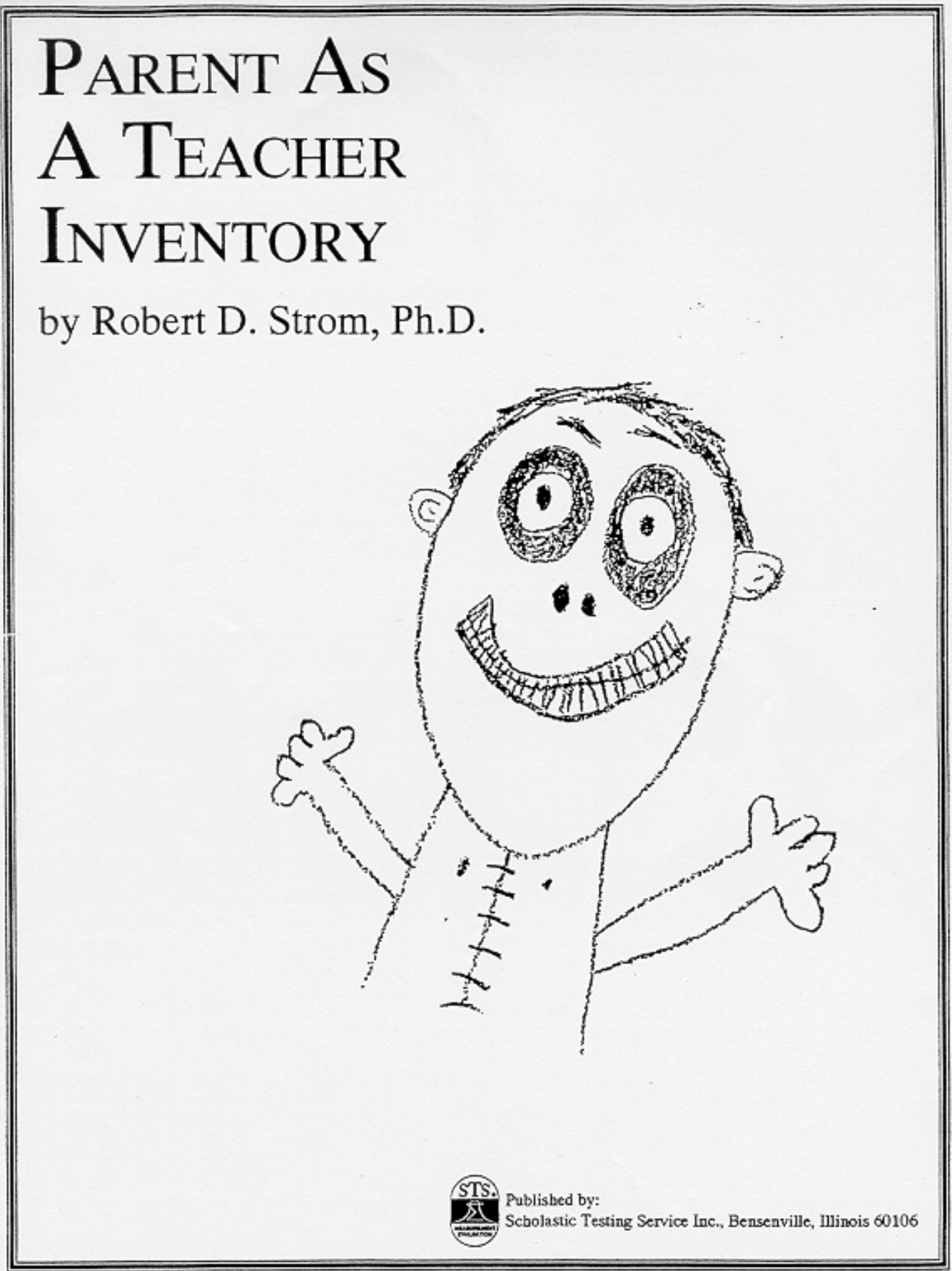


Directions: You will be reading some statements about your child. For each statement, circle only one answer. If there is no doubt in your mind about the statement, circle either STRONG YES or STRONG NO. Otherwise, circle either YES or No. Continue until you have answered all fifty statements. Take your time, this is not a test.

1. I get tired of all the questions my child asks.

StRONG Yes Yes No STRONC No

2. My child should be able to make noise during play.

STRONG YES YES NO STRONG No

3. It is all right for my child to disagree with me.

$\begin{array}{llll}\text { STRONG YES } & \text { YES NO NTONG No }\end{array}$

4. My child needs to play with me.

$\begin{array}{llll}\text { STRONG YES NES NO NTONG No } & \text { YE }\end{array}$

5. Much of my child's learning will take place before he or she enters school.
Strong Yes
YES
No
STRONG No

6. I like my child to make up stories.
STRONG YES
YES
No
STRONG No

7. It gets on my nerves when my child keeps asking me to watch him or her play.

$\begin{array}{llll}\text { STRONG YES YES NO NONG No } & \text { Y }\end{array}$

8. I want my child to say more than I do when we talk
STRONG YES
YES
No
STRONG No

9. Playing with my child makes me feel restless.
STRONG YES
YES
No
STRONG No 
10. It is difficult for me to tell when my child has learned something.

$$
\begin{array}{llll}
\text { STRONG YES } & \text { YES NO NONG NO }
\end{array}
$$

11. When my child doesn't know an answer, I ask the child to guess.

$\begin{array}{llll}\text { STRONG YES } & \text { YES NO STRONG No }\end{array}$

12. I get tired of all the fears that my child talks about.

$$
\text { StRONG YES Yes No Strong No .. }
$$

13. There are some things I just don't want my child to talk about.

$\begin{array}{llll}\text { STRONG YES } & \text { YES NOSONC NO }\end{array}$

14. If I spend a lot of time playing with my child, he or she will disobey me more often.

STRONG YES YES NO STRONG No

15. It is all right for my child to have a make-believe friend.

STRONG Yes Yes No STRONG No

16. I want my child to play with toys made for boys and toys made for girls.

$\begin{array}{llll}\text { STRONG YES } & \text { YES NTONG NO }\end{array}$

17. My child bothers me with questions when I am busy.

STRONG YES YES NO STRONG NO

18. I like my child to be quiet when adults are talking.

$\begin{array}{llll}\text { STRONG YES } & \text { YES NO }\end{array}$

19. I feel confident choosing new toys for my child.

$\begin{array}{llll}\text { STRONG YES YES NO STRONG NO } & \text { Y }\end{array}$

20. It is difficult for me to think of things to say to my child during play.

$\begin{array}{llll}\text { StRONG Yes } & \text { Yes } & \text { No }\end{array}$

21. When my child plays with toys, the pretending seems foolish.

$\begin{array}{llll}\text { STRONG YES } & \text { YES NTONG NO }\end{array}$ 
22. My child is punished for fighting during play.

$\begin{array}{llll}\text { StRONG Yes } & \text { Yes } & \text { No }\end{array}$

23. While we play, my child should be the person in control.

$\begin{array}{llll}\text { STRONG YeS } & \text { Yes NO NONG No }\end{array}$

24. Playing with my child improves the child's behavior.

$\begin{array}{llll}\text { StRONG Yes } & \text { Yes NO NTRONG No }\end{array}$

25. When I play with my child I feel the need to talk like a child.

$\begin{array}{llll}\text { STRONG YeS } & \text { Yes } & \text { No }\end{array}$

26. I want my child to have all of his or her questions answered.

$\begin{array}{llll}\text { STRONG YES } & \text { YES NO NONG NO }\end{array}$

27. It is all right for my child to get dirty while at play.

$\begin{array}{llll}\text { STRONG Yes } & \text { YES NO NONG No }\end{array}$

28 . When at play with my child, I prefer games with rules rather than make-believe play.

$\begin{array}{llll}\text { STRONG YES YES NO NONG No } & \text { Y }\end{array}$

29. My child learns new words when we play.

$$
\text { STRONG YES YES NO STRONG NO }
$$

30. I feel able to give my child the proper preschool experience at home.

$\begin{array}{llll}\text { STRONG YES } & \text { YES NO STRONG NO }\end{array}$

31. I get upset when my child tries to solve a simple problem in the wrong way.
StRONG YES
YES
No
StRONG No

32. It is all right for my child to interrupt me when we play together.
STRONG Yes
YES
No
Strong No

33. I feel play must be stopped when my child becomes angry at a playmate.

$\begin{array}{llll}\text { STRONG YES YES NO STRONG NO } & \text { YO }\end{array}$


34. I try to praise my child a lot when we play.

$$
\begin{array}{llll}
\text { STRONG YES } & \text { YES NO NTONG NO }
\end{array}
$$

35. My child's personality learning occurs mostly from watching people.

$\begin{array}{llll}\text { STRONG YES } & \text { YES NO NTRONG NO }\end{array}$

36. It is all right for my child to spend a lot of time playing alone.

$\begin{array}{llll}\text { StRONG Yes } & \text { Yes } & \text { No }\end{array}$

37. While at play, my child can take out as many toys as he or she wishes.

STRONG YES YES NO STRONG No

38. I provide chances for my child to make up his or her own mind about a lot of things.

$$
\text { STRONG YES YES NO STRONG No }
$$

39. It is difficult for me to stay interested when playing with my child.

$$
\text { STRONG YES YES NO STRONG NO }
$$

40. I punish my child when he or she doesn't learn.

$\begin{array}{lll}\text { STRONG YES YES NO STRONG No } & \text { Y }\end{array}$

41. My child wants to play too long at one time.

$\begin{array}{llll}\text { STRONG YES YES NO STRONG NO } & \text { YE }\end{array}$

42. When my child shows off I ignore it.

$\begin{array}{lll}\text { STRONG YES YES NO STRONG NO } & \text { Y }\end{array}$

43. I feel unhappy when I don't know an answer to my child's questions.

$\begin{array}{llll}\text { STRONG YES } & \text { YeS } & \text { NO }\end{array}$

44. I imitate my child's speech when we play so that the child understands.

$\begin{array}{llll}\text { STRONG YES } & \text { YES } & \text { No }\end{array}$

45. It is easy for me to use toys when teaching my child.

$\begin{array}{llll}\text { StRONG YES } & \text { YES NO NO NONG No }\end{array}$ 
46. I seldom tell my child his or her work is good or bad so that my child can be the judge.

$$
\text { STRONG YES YES NO STRONG No }
$$

47. I want my child to put the toys away before going to bed.

STRONG YES YES NO STRONG NO

48. It is all right for my child to have secrets from me.

$$
\text { STRONG YES YES NO STRONG NO }
$$

49. My child learns by playing with other children.

$$
\begin{array}{lll}
\text { STRONG Yes } & \text { Yes NO NONG No }
\end{array}
$$

50. If we play whenever my child wants to, not much learning will take place.

$\begin{array}{llll}\text { STRONG YES YES NO STRONG No } & \text { YE }\end{array}$


$\underline{\text { APPENDIX E }}$

THINKING CREATIVELY IN ACTION AND MOVEMENT (TCAM) 


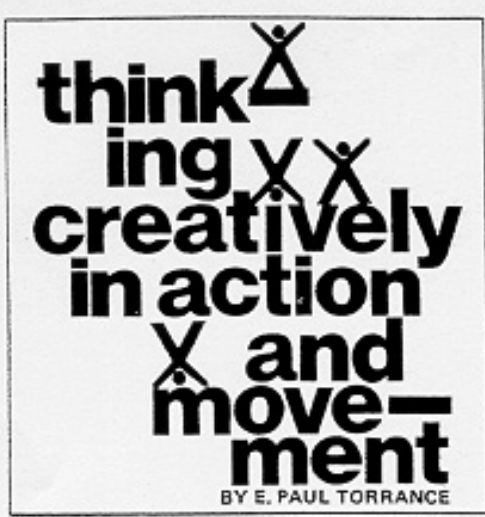

\begin{tabular}{ll} 
NAME & DATE \\
\hline AGE & SEX \\
\hline EXAMINER & \\
\hline & \\
\hline
\end{tabular}

\begin{tabular}{|c|c|c|c|}
\hline scores & flu. & orig. & imag. \\
\hline activity 1 (How Many Ways?) & & & \\
\hline activity 2 (Can You Move Lika? & & 2 & \\
\hline activity 3 (What Other Ways?) & & & \\
\hline $\begin{array}{r}\text { activity } 4 \text { (What Can You Do } \\
\text { with a Paper Cup?) }\end{array}$ & & & \\
\hline \multicolumn{4}{|l|}{ TOTAL } \\
\hline STANDARD SCORE & & & \\
\hline
\end{tabular}




\section{ACTIVITY ONE (How Many Ways?)}

Today we will have a lot of fun moving in interesting ways. I want you to think up as many ways as you can to walk or run. Do you see this piece of red tape? We will start running or walking here, and will go to the other side of the room until we get to the piece of yellow tape. (Walk between the two pieces of tape with the child)

Now it is your turn to walk and run for me. Think up as many fun ways as you can. While you are moving, I will sit here and write. You may begin now. (Do not give hints but continue motivating the child to show as many ways as he can for getting across the room. List each one.)

1.

2.

3.

4.

5.

6.

7.

8.

9.

10.

11.

12.

13.

14.

15.

16.

17.

18.

19.

20.

21.

22.

23.

24.

25.

26.

27.

28.

29.

30.

Time: 


\section{ACTIVITY TWO (Can You Move Like?)}

Now we are going to do some more fun things. This time we are going to pretend. Sometimes we pretend we are birds, elephants, or horses. Other times we pretend we are throwing or catching a ball. (Warm-up by mimicking a bird flying, an elephant walking, and throwing and catching a ball. Encourage the child to act along with you.)

Now I am going to name several things and you can pretend that you are doing them. You don't have to tell me anything. You can just show me. (Circle the number that corresponds with the child's response.)

1. Can you move like a tree in the wind? Imagine you are a tree and the wind is blowing very hard. Show how you would move.
12
3
$4 \quad 5$
No movement
Adequate
Excellent; like the thing

2. Can you move like a rabbit? Imagine you are a rabbit and somebody is chasing you. Show how you would hop.
1
3
4
5
No movement
Adequate
Excellent; like the thing

3. Can you move like a fish? Imagine you are a fish in a river or pond. Show how you would swim.
1
2
3
4
5
No movement
Adequate
Excellent; like the thing

4. Can you move like a snake? Imagine you are a snake crawling in the grass. Show how you would crawi.
12
23
34
5
No movement
Adequate
Excellent; like the thing

5. Can you move like you are driving a car? Imagine you are driving your car on the highway. Show how you would drive.
12
3
4
5
No movement
Adequate
Excellent; like the thing

6. Can you push an elephant? Imagine a big elephant is standing on something you want. Show how you would push him to make him move off of the thing you want.
12
3
Adequate
4
5
Excellent; like the thing

Total Score:

Time: 


\section{ACTIVITY THREE (What Other Ways?\}}

Here is a cup just like the one you drink juice from. Can you put it in the wastebasket? Show me how you would do it. (Pause.) Good. Now let's see how many other ways you can put the cup in the wastebasket. You don't have to say anything. Just show me. I have many cups and you can use as many as you want. (List all responses. Accept verbal responses from children who are inhibited about acting.)

$$
1 .
$$

2.

3.

4.

5.

6.

7.

8.

9.

10.

11.

12.

13.

14.

15.

16.

17.

18.

19.

20.

21.

22.

23.

24.

25.

26.

27.

28.

29.

30.

Time: 


\section{ACTIVITY FOUR (What Can You Do With a Paper Cup?}

You just thought of many ways to put a paper cup in the wastebasket. But sometimes you don't want to put your cup in the wastebasket. Instead you might want to play with it or imagine that it is something else. Let's see how many different things you can do with this juice cup. Show me or tell me. have many cups for you to use. (List all responses).

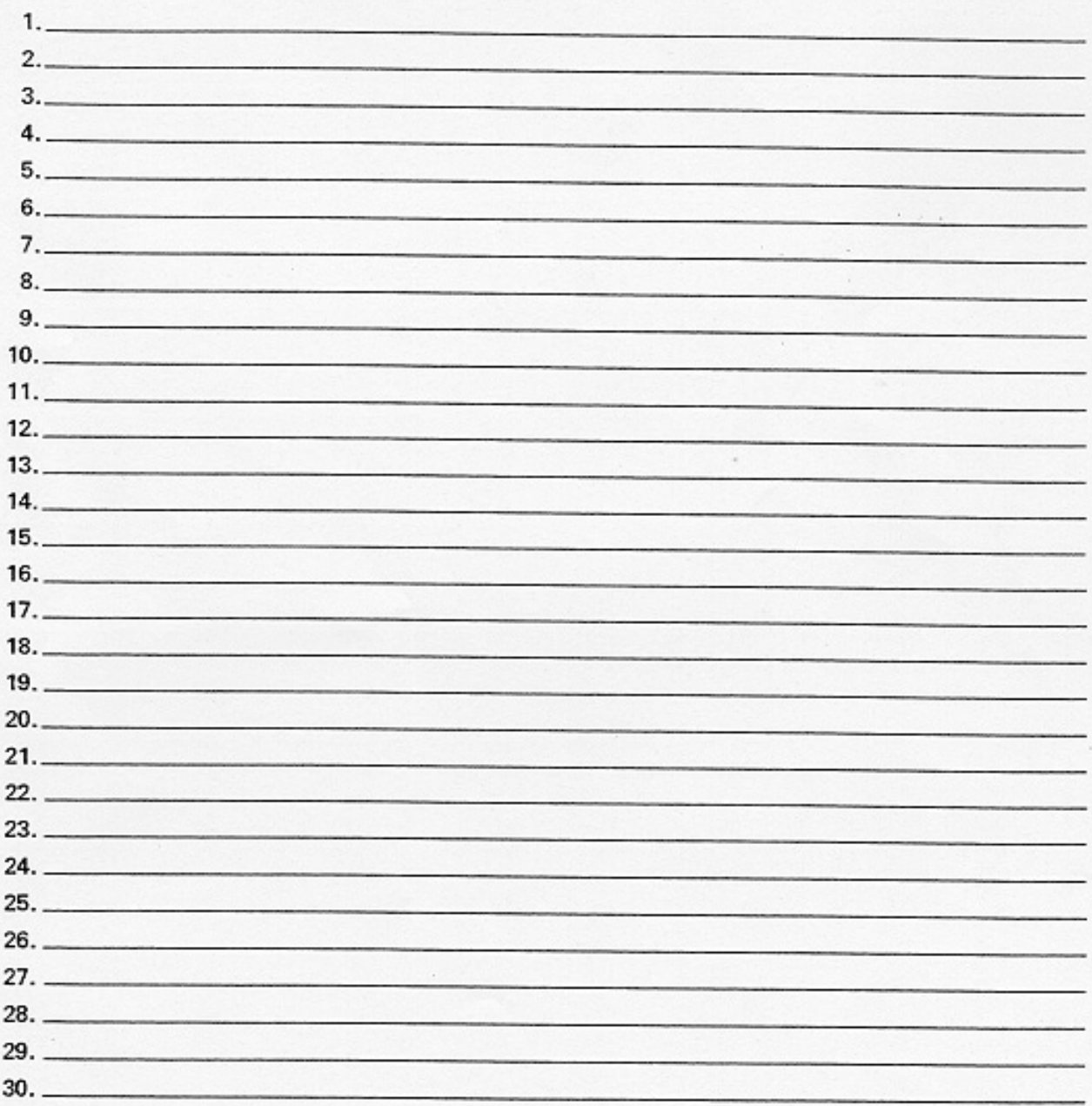

Time: 